\title{
Adenovirus Vector Harboring the HBcAg and Tripeptidyl Peptidase II Genes Induces Potent Cellular Immune Responses In Vivo
}

\author{
Quanhui Tan Siyuan Ma Jianjun Hu Xiaohua Chen Yongsheng Yu Guoqin Zang \\ Zhenghao Tang
}

Department of infection Disease, Shanghai Jiao Tong University Affiliated Sixth People's Hospital, Shanghai, P.R.China

\section{Key Words}

Tripeptidyl peptidase II • JAK/STAT signaling pathway • T-bet • GATA-3 • MHC class I

\begin{abstract}
Background: Chronic hepatitis B virus (HBV) infection is associated with a weak but specific cellular immune response of the host to HBV. Tripeptidyl peptidase II (TPP II), an intracellular macromolecule and proteolytic enzyme, plays an important complementary and compensatory role for the proteasome during viral protein degradation and major histocompatibility complex class I antigen presentation by inducing a specific cellular immune response in vivo. Based on a previous study, we aimed to explore the role of MHC class I antigen presentation in vivo and the mechanisms that may be involved. Methods: In this study, recombinant adenoviral vectors harboring the hepatitis $B$ core antigen $(\mathrm{HBCAg})$ and the TPPII gene were constructed (Adv-HBcAg and Adv-HBcAg-TPPII), and $\mathrm{H}-2 \mathrm{Kd} \mathrm{HBV}$-transgenic $\mathrm{BALB} / \mathrm{c}$ mice and HLA-A2 C57BL/6 mice were immunized with these vectors, respectively. We evaluated the specific immune responses induced by Adv-HBcAg-TPPII in the HBV transgenic BALB/c mice and HLA-A2 C57BL/6 mice as well as the anti-viral ability of HBV transgenic mice, and we explored the underlying mechanisms. Results: We found that immunization with Adv$\mathrm{HBCAg}$-TPPII induced the secretion of the cytokines interleukin-2 (IL-2), interferon- $\gamma$ (IFN- $\gamma$ ) and tumor necrosis factor- $\alpha$ (TNF- $\alpha$ ) as well as the activities of IFN- $\gamma$-secreting CD8 + T cells and CD4+ T cells. In addition, HBcAg-specific CTL activity in C57/BL mice and HBV transgenic animals was significantly enhanced in the Adv-HBcAg-TPPII group. Furthermore, Adv-HBcAgTPPII decreased the hepatitis B surface antigen (HBsAg) and HBV DNA levels and the amount of $\mathrm{HBsAg}$ and $\mathrm{HBCAg}$ in liver tissues. Moreover, Adv-HBcAg-TPPII enhanced the expression of T-box transcription factor (T-bet) and downregulated GATA-binding protein 3 (GATA-3) while increasing the expression levels of JAK2, STAT1, STAT4 and Tyk2. Conclusions: These results suggested that the JAK/STAT signaling pathway participates in the CTL response that is mediated by the adenoviral vector encoding TPPII. Adv-HBcAg-TPPII could therefore break immune tolerance and stimulate HBV-specific cytotoxic T lymphocyte activity and could have a good therapeutic effect in transgenic mice.
\end{abstract}




\section{Cellular Physiology Cell Physiol Biochem 2017;41:423-438

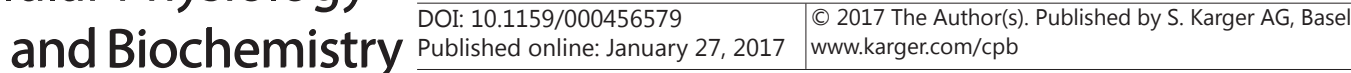 \\ Tan et al.: Adv-HBcAg-TPPII Enhance CTL Response}

\section{Introduction}

Hepatitis B virus infection causes chronic hepatitis and complications that can pose serious hazards to human health worldwide $[1,2]$. As reported by the World Health Organization, approximately 2 billion people have been infected with the hepatitis B virus [3], with over 400 million people developing chronic hepatitis [4, 5]. Chronic hepatitis B patients with persistent HBV infection have immune disorders and immune tolerance [6]. Therefore, developing new treatments for chronic hepatitis B is essential and requires a further exploration of the mechanisms underlying the interactions between hepatitis B virus and the host immune system.

The control, outcome and clearance of HBV infection depend on the state of the host's immune system. The effective removal of HBV and the establishment of long-term immune protection by the body mainly depend on HBV-specific CD8 ${ }^{+} \mathrm{T}$ lymphocytes [7]. Cytotoxic $\mathrm{T}$ lymphocytes (CTLs) can recognize the viral peptides that damage $\mathrm{T}$ cell receptors and can cause cytolysis by presenting MHC class I molecules, which is crucial for clearing HBV infection. Previous studies have indicated that a weak CTL response may be the major cause of chronic hepatitis B [8].

MHC class I antigen processing is mediated by the ubiquitin proteasome [9], in association with molecular chaperones and calcium-binding proteins, and ultimately results in viral antigen degradation by ubiquitin. The ubiquitin protease system (UPS) surveys the peptides on MHC class I molecules that form the MHC class I complexes and expresses them on the APC surface via the secretory pathway, thereby activating the CTL response. Abnormal pathological proteins can be degraded independent of the ubiquitin-proteasome system. Tripeptidyl peptidase II (TPP II) has attracted increasing attention as a small peptidic enzyme that degrades macromolecular proteins $[10,11]$. TPPII has been described in virtually all eukaryotic cells. The main function of TPPII is to ensure a healthy environment for the cells by cleaning misfolded proteins or those that have already played their roles. In addition, TPPII has an ability similar to that of proteasomes: target protein degradation [12, 13]. Studies have demonstrated that TPPII causes the intracellular accumulation of proteins with reduced function, accompanied by the reduced synthesis of free amino acids [14].

After a thorough assessment of its ultrastructural and functional properties, mounting evidence suggests that TPPII is involved in both the degradation of MHC class I molecules and the presentation process. A variety of viruses and tumor proteins with reduced or no sensitivity to proteasomal inhibition can be eliminated by TPPII degradation [15]. Moreover, such proteins can induce specific CTL responses after degradation.

Considering the special role of the proteasome in the degradation pathways of viral antigens, reports have suggested that proteasomal degradation would produce considerable amounts of macromolecular peptides. However, peptides larger than 15 amino acids are not suitable for MHC class I molecules.

Meanwhile, TPPII not only can degrade abnormal proteins but also further degrades primary degradation peptidic products into peptides of less than 15 amino acids, which are more easily trafficked into the endoplasmic reticulum and combined with MHC class I molecules [16].

Based on the above findings, the proteasome function of dendritic cells (DCs) is decreased in chronic viral infection, which contributes to the occurrence of chronic viral infection and immune tolerance. Therefore, TPPII is complementary and an alternative to the proteasome as a necessary peptidic enzyme that possesses the powerful ability of antigen degradation and presentation.

Hepatitis B virus core protein is an antigen that can induce cell immunity, which then clears the hepatitis B virus infection [17]. It effectively activates the host CTL response compared with other HBV proteins. TPPII can degrade the HBcAg peptide and present it during chronic HBV infection, and the proteasome activity, synthesis, and function are decreased. It could produce suitable peptides for MHC class I molecules to induce HBVspecific CTL. JAK/STAT signaling plays a key role in the differentiation of Th1, Th2 and Th17. 


\section{Cellular Physiology Cell Physiol Biochem 2017;41:423-438 \begin{tabular}{ll|l} 
and Biochemistry $10.1159 / 000456579$ & $\begin{array}{l}\text { D 2017 The Author(s). Published by S. Karger AG, Basel } \\
\text { www.karger.com/cpb }\end{array}$ \\
\hline
\end{tabular} \\ Tan et al.: Adv-HBCAg-TPPII Enhance CTL Response}

This study constructed an adenovirus encoding HBcAg that was transfected into DCs. The HBcAg peptide should be degraded into suitably sized peptides for MHC class I molecules to induce HBV-specific CTL responses. In addition, we investigated the expression of the JAK/ STAT pathway downstream transcription factors to determine the association of the JAK/ STAT pathway with the CTL responses induced by HBcAg after TPPII degradation. The aim of this study was to assess the mechanism and capacity of DCs induced by HBcAg, as mediated by the adenovirus vector, to stimulate lymphocyte proliferation and generate HBV-specific CTL responses. The results may be helpful in developing novel approaches for controlling persistent HBV infection and can provide new insights for immune therapy in chronic HBV infection.

\section{Materials and Methods}

Mice and ethics statement

Sixty HLA-A2 C57BL/ 6 mice (30 males and 30 females, 4-6 weeks old) were purchased from Shanghai Shrek Animal Co., LTD(Shanghai,China). Sixty $H-2 K^{d}$ HBV-transgenic BALB/c mice (30 males and 30 females, 4-6 weeks old) were obtained from the Key Liver Army Laboratory (The No.458 Hospital, Guangzhou, China). These mice contained 1.3 copies of the HBV genome. The levels of HBsAg and HBV DNA in the serum were higher than those in normal mice, as detected by enzyme-linked immunosorbent assay. The expression of HBsAg and HBcAg in hepatocytes was detected by histology and immunohistochemistry of liver tissues. The mice were bred in the Shanghai Sixth People's Hospital Animal Experiment under specific pathogenfree conditions. The mice were cared for and treated in accordance with the guidelines established by the Shanghai Public Health Service Policy on the Humane Care and Use of Laboratory Animals.

Cells

P815/c cells

The P815/c cells expressing HBcAg were stored in our laboratory. After transfection by adenoviruses encoding HBcAg and TPPII,P815/c cells were supplemented with $2 \mathrm{~g} / \mathrm{ml}$ puromycin for screening for 10 days after $48 \mathrm{~h}$ of transduction. Human embryonic kidney 293T cells were obtained from the American Type Culture Collection (Manassas, VA, USA). The cells were cultured in Dulbecco's modified Eagle's medium (DMEM; Invitrogen, Gaithersburg, MD, USA) containing 10\% fetal bovine serum (FBS; Gibco, Grand Island, NY, USA), $100 \mathrm{U} / \mathrm{ml}$ penicillin, and $100 \mu \mathrm{g} / \mathrm{ml}$ streptomycin at $37^{\circ} \mathrm{C}$ in a humidified atmosphere with $5 \%$ $\mathrm{CO} 2$.

\section{Immunization of the mice}

Recombinant adenoviral vectors were constructed as described previously. The adenoviral vector plasmid was supplied by Obio Technology Co., Ltd. (Shanghai, China). AG490 is considered a specific inhibitor of JAK2 and was used to assess whether the JAK/STAT signaling pathway is involved in mediating the CTL response induced by the recombinant adenoviral vectors.

HLA-A2 C57BL/6 mice were randomly divided into six groups ( $n=10)$ : empty virus (control group), empty virus group and blocker (AG490), HBcAg recombinant adenovirus (HBcAg), HBcAg recombinant adenovirus and blocker (HBcAg/AG490), HBcAg/TPPII recombinant adenovirus (HBcAg/TPPII), and HBcAg/TPPII recombinant adenovirus and blocker AG490 (HBcAg/TPPII/AG490). Recombinant adenovirus samples were administered by tail vein injection with $2 \times 10^{9}$ particle forming units (PFU) four times at 1-week intervals. Additionally, HLA-A2 C57BL/6 mice were subcutaneously injected with AG490 (5 mg/kg) every day for one month in the indicated groups. Mice were sacrificed after immunization, and splenocytes and livers were collected for analysis.

$H-2 K^{d} \mathrm{HBV}$-transgenic BALB/c mice were also divided into six groups and injected in the footpad with the recombinant adenovirus vectors (Adeno, Adv-HBcAg and Adv-HBcAg-TPPII) at $2 \times 10^{9} \mathrm{PFU}$ at 1-week intervals, with 20,000 IU interferon- $\alpha$ (IFN- $\alpha$ ) (Roche Diagnostics, Basel, Switzerland), 50 g HBcAg (Cal Bioreagents, Inc., San Mateo, CA, USA) and phosphate-buffered saline (PBS). The mice were sacrificed at the indicated time points. Blood samples were collected at 1-week intervals, four times in all. Splenocytes and livers were collected for detection. 


\section{Cellular Physiology Cell Physiol Biochem 2017;41:423-438 \begin{tabular}{ll|l} 
and Biochemistry $10.1159 / 000456579$ & $\begin{array}{l}\text { Published on } 2017 \text { The Author(s). Published by S. Karger AG, Basel } \\
\text { www.karger.com/cpb }\end{array}$ \\
\hline
\end{tabular} \\ Tan et al.: Adv-HBcAg-TPPII Enhance CTL Response}

Assessment of the levels of the cytokines IFN- $\gamma, I L-2, T N F-\alpha, I L-4$ and $I L-10$

Splenocytes $\left(2 \times 10^{6} \mathrm{cells} / \mathrm{ml}\right)$ were collected from the immunized $H-2 K^{d} \mathrm{HBV}$-transgenic BALB/c mice and HLA-A2 C57BL/ 6 mice one week after the last immunization. Then, T cells were separated using the nylon filtration method, as described previously [18]. These cells were then co-cultured with $10 \mu \mathrm{g} / \mathrm{ml}$ $\mathrm{HBcAg}$ at $37^{\circ} \mathrm{C}$ in a humidified atmosphere with $5 \% \mathrm{CO} 2$. After $72 \mathrm{~h}$ of incubation, the levels of IFN- $\gamma$, IL-2, TNF- $\alpha$, IL-4 and IL-10 in the supernatants were detected by specific mouse cytokine ELISA kits (R\&D Co., Ltd., Minneapolis, USA), according to the manufacturer's protocols. The results were expressed as $\mathrm{pg} / \mathrm{ml}$.

\section{Detection of IFN- $\gamma$ production by flow cytometry and ELISPOT}

The percentages of IFN- $\gamma$ secreting cells were assessed by flow cytometry and enzyme-linked immunospot (ELISPOT) assay. The splenocytes were incubated with $10 \mu \mathrm{g} \mathrm{HBcAg}$ for 6 hours, followed by treatment with PMA $(25 \mathrm{~g} / \mathrm{ml})$, ionomycin $(1 \mathrm{~g} / \mathrm{ml})$ and monensin $(1.7 \mathrm{~g} / \mathrm{ml})$ for 3 hours [19]. Then, the cells were washed with PBS twice and stained with FITC-CD8 $\alpha$ or FITC-CD 4 antibodies for 30 minutes. After incubation with fixation buffer (BD Biosciences, San Jose, CA, USA) for 15 minutes and with permeabilization reagent (BD Biosciences, San Jose, CA, USA) for 5 minutes, the cells were stained with PE-conjugated antiIFN- $\gamma$ McAb (eBioscience) for 30 minutes and analyzed by flow cytometry.

IFN- $\gamma$ secreting cells were assessed by ELISPOT according to the manufacturer's instructions using an anti-IFN- $\gamma$ McAb; briefly, $10 \mu \mathrm{g} / \mathrm{ml} \mathrm{HBcAg}$ peptide was added to the splenocytes ( $5 \times 10^{5}$ cells/well) obtained from the immunized mice and seeded in six-well plates. The cells were incubated at $37^{\circ} \mathrm{C}$ under $5 \%$ CO2 for 20 hours. Positive and negative controls were set in each assay. Secondary antibodies were added for 1 hour at room temperature. After five washes, the cells were stained with streptavidin -HRP for 1 hour and washed. The AEC solution was added for spot development. Subsequently, the spots were counted on a Bioreader 4000 PRO-X (Bio-Sys GmbH, Karben, Germany). Data were presented as spot-forming-cells (SFC) per $10^{6}$ splenocytes.

\section{Evaluation of the CTL response}

T lymphocytes were obtained from the splenocytes using nylon wool columns (Wako, Tokyo, Japan) as previously described [20]. P815/c cells $\left(5 \times 10^{4}\right.$ cells/well), which were used as target cells, were seeded in 96-well plates. As effector cells, T lymphocytes were co-cultured with P815/c cells at different effectorto-target (E/T) ratios $(5: 1,10: 1$, and $20: 1)$ at $37^{\circ} \mathrm{C}$ with $5 \% \mathrm{CO} 2$ for $4 \mathrm{~h}$. The lactate dehydrogenase (LDH) release assay was used to assess HBcAg-specific CTL activity (CytoTox 96® nonradioactive cytotoxicity kit; Promega, Madison, USA). LDH in the supernatants was detected at $490 \mathrm{~nm}$. Cytotoxicity (\%) was calculated as follows: [(experimental release - effector spontaneous release-target spontaneous release)/(target maximum release - target spontaneous release)] $\times 100 \%[21,22]$.

\section{Serological analysis}

The serum HBsAg and HBV DNA levels were assessed one week after the first and last immunizations in $H-2 K^{d} \mathrm{HBV}$-transgenic BALB/c mice. The serum HBsAg and HBV-DNA amounts were detected using Abbott kits (Abbott Diagnostics, Chicago, USA) and quantitative PCR (TranGen Biotech, Beijing, China), respectively. The changes in the HBsAg and HBV-DNA levels were evaluated in each group. Furthermore, the serum alanine aminotransferase (ALT) and aspartate transaminase (AST) amounts were determined using an ARCHITECT Automatic Biochemistry Analyzer (Abbott Diagnostics).

\section{Liver histology and immunohistochemistry}

Liver tissues were obtained from the immunized mice, fixed in formaldehyde, and embedded in paraffin. The dewaxed 3- to 5- $\mu$ m-thick sections were stained with hematoxylin and eosin (H\&E). For immunohistochemistry, liver tissue sections were treated with $0.3 \% \mathrm{H}_{2} \mathrm{O}_{2}$ for 10 minutes to inactivate the endogenous peroxidase during dewaxing and blocked with $2 \%$ normal goat serum for 30 minutes at room temperature. Then, goat anti-HBsAg and anti-HBcAg polyclonal antibodies were added overnight at $4^{\circ} \mathrm{C}$. After three washes with PBS, the sections were stained with secondary antibody for 30 minutes at $37^{\circ} \mathrm{C}$ and incubated with the streptavidin-biotin-peroxidase complex for 30 minutes. Visualization was carried out with diaminobenzidine (DAB, Boster) and counterstaining with hematoxylin. 


\section{Cellular Physiology Cell Physiol Biochem 2017;41:423-438

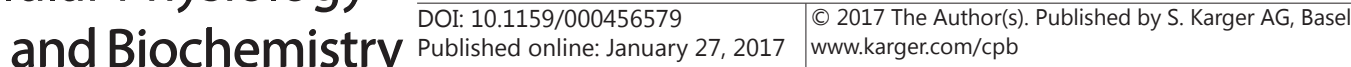

Tan et al.: Adv-HBcAg-TPPII Enhance CTL Response

Gene expression levels of T-bet/GATA-3 and JAK/STAT signaling pathway effectors

T-lymphocytes were harvested from $H-2 K^{d} \mathrm{HBV}$-transgenic BALB/c mice and HLA-A2 C57BL/6 mice for total RNA isolation by TRIzol Reagent. Total RNA was processed to generate cDNA using PrimeScript RT Reagent Kit. Semi-quantitative real-time PCR was performed according to routine protocols to detect JAK2, TyK2, STAT1, and STAT4 in the JAK/STAT signaling pathway. T-bet and GATA-3 participate in Th1 and Th2 cell differentiation, respectively; therefore, their mRNA levels were assessed in the HBV transgenic mice.

The PCR primers were as follows:

JAK2, forward 5'-GGCAGCAGCAGAACCTAC-3' and reverse 5'-GTCTAACACCGCCATCCC-3'; Tyk2, forward 5'-TTCCGTAGCAACCGTCTC-3' and reverse 5'-CATCAAGCATCCTGTGGG-3'; STAT1, forward 5'-CTATGAGCCCGACCCTAT-30' and reverse 5'-TTGAACTTCCGAAATCCT-3'; STAT4 forward 5'-CCTGCTGTTGGTTGGTGT-3' and reverse 5'-CTTGAGGCTTTCCTGTGC-3'; GAPDH forward 5'-AGAAGGCTGGGGCTCATTTG-3' and reverse 5'-AGGGGCCATCCACAGTCTTC-3'; T-bet, forward 5'-CTAAAGCTCACCAACAACAAGGG-3' and reverse 5'-CAGATGCGTACATGGACTCAAAG-3'; GATA-3, forward 5'-TACAGCTCTGGACTCTTCCCAC-3' and reverse 5'-TTCGCTTGGGCTTGATAAGG-3'; GAPDH, forward 5'-GTGACGTTGACATCCGTAAAGA-3' and reverse 5'-GTAACAGTCCGCCTAGAAGCAC-3'. PCR was carried out at $95^{\circ} \mathrm{C}$ for $30 \mathrm{~s}$, followed by 40 cycles at $95^{\circ} \mathrm{C}$ for $15 \mathrm{~s}$ and $60^{\circ} \mathrm{C}$ for $60 \mathrm{~s}$. Data were analyzed using the $2^{-\triangle \Delta \mathrm{Ct}}$ method, with GAPDH used for normalization.

Quantitation of protein expression

Cells were lysed in the RIPA lysis buffer (Beyotime Institute of Biotechnology, Jiangsu, China), and the protein concentrations in the lysates were determined using the Pierce BCA Protein Assay Reagent Kit (Rockford, IL, USA). Equal amounts of proteins were separated by SDS-PAGE and transferred onto Immobilon-PVDF membranes (Millipore, Bedford, MA, USA) on a semi-dry apparatus (Bio-Rad, Hercules, CA, USA). Rabbit anti-JAK2, Tyk2, STAT1, STAT4, T-bet and GATA-3 were used as primary antibodies, and horseradish peroxidase-conjugated goat anti-rabbit immunoglobulin-G antibody was used as a secondary antibody.

\section{Statistical analysis}

Data are presented as the mean \pm standard deviation. The HBV DNA levels were expressed logarithmically. Different groups were compared by one-way analysis of variance (ANOVA) with post hoc least significant difference tests. The SPSS19.0 software was used for statistical analyses. $\mathrm{P}<0.05$ was considered statistically significant.

\section{Results}

Adv-HBcAg-TPPII enhanced Th1-like cell secreting cytokines

Many cytokines have been shown to be involved in the HBV infection process [23]. The cytokines IFN- $\gamma$, IL-2, TNF- $\alpha$ (Th1-like), and IL-4 and IL-10 (Th2-like) that were secreted in splenocytes obtained from immunized HLA-A2 C57BL/6 mice were analyzed in the presence of HBcAg $(10 \mathrm{~g} / \mathrm{ml})$. As shown in Fig. 1A, splenocytes of the Adv-HBcAg-TPPII group secreted higher levels of IFN- $\gamma(574.27 \pm 23.37 \mathrm{pg} / \mathrm{ml})$, IL-2 (582.90 $\pm 36.82 \mathrm{pg} /$ $\mathrm{ml})$ and TNF- $\alpha(467.07 \pm 10.92 \mathrm{pg} / \mathrm{ml})$ than did all other groups except the Adv-HBcAgTPPII/AG490 group. However, the differences in the IL-4 and IL-10 (Th2-like) levels were not statistically significant between the groups. Splenocytes from immunized $H-2 K^{d} \mathrm{HBV}$ transgenic BALB/c mice were analyzed in the same way. As shown in Fig. 1B, the Adv-HBcAgTPPII group showed higher levels of IFN- $\gamma(154.27 \pm 13.37 \mathrm{pg} / \mathrm{ml}), \mathrm{IL}-2(342.90 \pm 16.82 \mathrm{pg} /$ $\mathrm{ml})$ and TNF- $\alpha(1567.07 \pm 14.92 \mathrm{pg} / \mathrm{ml})$ compared with the other groups. The differences in IL-4 and IL-10 (Th2-like) levels among these groups were not statistically significant.

\section{Adv-HBcAg-TPPII induced IFN- $\gamma$ production in $\mathrm{HBcAg}$-specific CD $8^{+} \mathrm{T}$ and $\mathrm{CD} 4^{+} \mathrm{T}$ cells}

The intracellular production of $\mathrm{CD}^{+}$and $\mathrm{CD}^{+} \mathrm{T}$ lymphocytes in immunized mice was detected by flow cytometry. As shown in Fig. 2A, C and E, the Adv-HBcAg-TPPII group displayed higher IFN $\gamma^{+} \mathrm{CD}^{+}$and IFN $\gamma^{+} \mathrm{CD}^{+} \mathrm{T}$ lymphocytes in immunized $\mathrm{HBV}$ transgenic mice compared with other groups. This result indicated that the Adv-HBcAg-TPPII group 

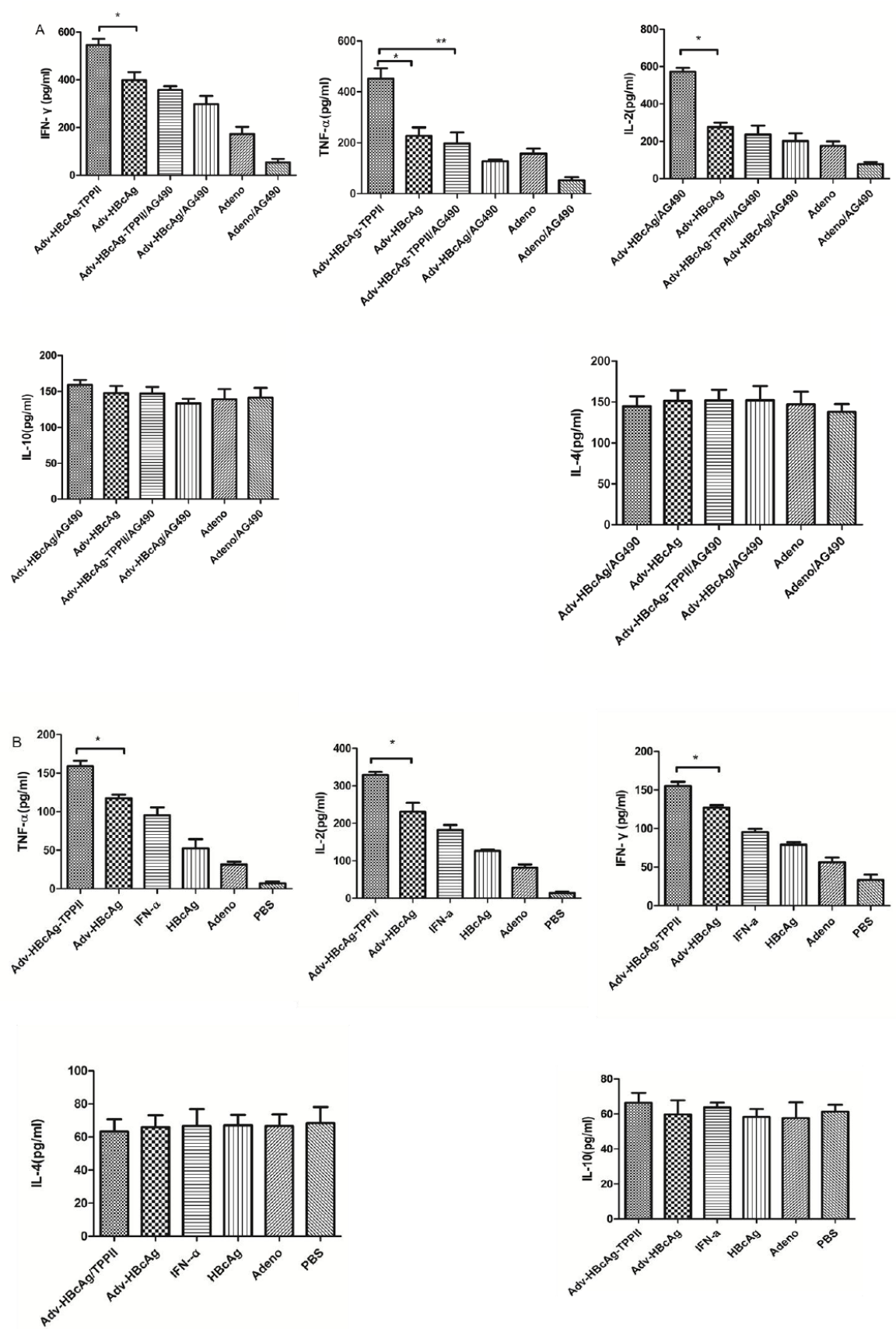

Fig. 1. Expression of the cytokines IL-2, IL-4, TNF- $\alpha$, IFN- $\gamma$ and IL-10. (A) Protein levels of IFN- $\gamma$, IL-2 and TNF- $\alpha$ in the supernatants of T cells from Adv-HBcAg -TPPII immunized C57BL/6 mice were significantly higher than the values obtained in the other groups $\left({ }^{*} \mathrm{p}<0.05\right)$. After treatment with AG490, the IL-2, IFN- $\gamma$ and TNF- $\alpha$ levels were obviously reduced ( $\left.{ }^{*} \mathrm{p}<0.05\right)$. (B) IL-2, IL-4, IFN- $\gamma$, TNF- $\alpha$ and IL-10 amounts in transgenic mice. The secretion levels of IL-2, IFN- $\gamma$ and TNF- $\alpha$ were significantly higher in the Adv-HBcAg-TPPII group than in the other groups $\left({ }^{*} \mathrm{p}<0.05\right)$. Secretion of IL-4 and IL-10 in the supernatants of T cells from immunized C57BL/6 and HBV transgenic mice. There were no statistically significant differences among the groups. Data are from at least three independent experiments and presented as the mean $\pm S D(n=6)$ $\left({ }^{*} \mathrm{p}<0.05,{ }^{* *} \mathrm{p}<0.01\right)$.

stimulated an increased, potent and specific $\mathrm{CD}^{+} \mathrm{T}$ cell response compared with the other groups in immunized $H-2 K^{d} \mathrm{HBV}$-transgenic BALB/c mice. As shown in Fig. 2B, D and E, 
Fig. 2. Intracellular IFN- $\gamma$ production in $\mathrm{CD}^{+} \mathrm{T}$ and $\mathrm{CD}^{+} \mathrm{T}$ lymphocytes from HBV transgenic mice and C57BL/6 animals. Splenocytes were harvested two weeks after the last immunization and re-stimulated in vitro. (A) Secretion levels of IFN- $\gamma$ in CD8 ${ }^{+} \mathrm{T}$ lymphocytes and percentages of IFN- $\gamma+\mathrm{CD}^{+} \mathrm{T}$ cells in HBV transgenic mice. The cells were stained with FITC-CD8 $\alpha$ and PE-IFN- $\gamma$ antibodies and analyzed by flow cytometry. (B) Secretion levels of IFN- $\gamma$ in $\mathrm{CD}^{+}{ }^{+} \mathrm{T}$ lymphocytes and percentages of IFN $-\gamma+\mathrm{CD}^{+} \mathrm{T}$ cells in immunized C57BL/ 6 mice. The cells were stained with PE-CD8 $\alpha$ and FITC-IFN- $\gamma$ antibodies and analyzed by flow cytometry. (C) Secretion levels of IFN- $\gamma$ in CD $4{ }^{+} \mathrm{T}$ lymphocytes and percentages of IFN- $\gamma+\mathrm{CD} 4{ }^{+} \mathrm{T}$ cells in HBV transgenic mice. Cells were stained with FITC-CD $4 \alpha$ and PE-IFN- $\gamma$ antibodies and analyzed by flow cytometry. (D) Secretion levels of IFN- $\gamma$ in CD4+T lymphocytes and percentages of IFN $-\gamma+\mathrm{CD} 4^{+} \mathrm{T}$ cells in C57BL/ 6 mice. The cells were stained with FITC-CD $4 \alpha$ and PEIFN- $\gamma$ antibodies and analyzed by flow cytometry. Data are shown as the mean $\pm S D$ from three independent experiments, which were run in triplicate. ${ }^{*} \mathrm{P}<0.05$.
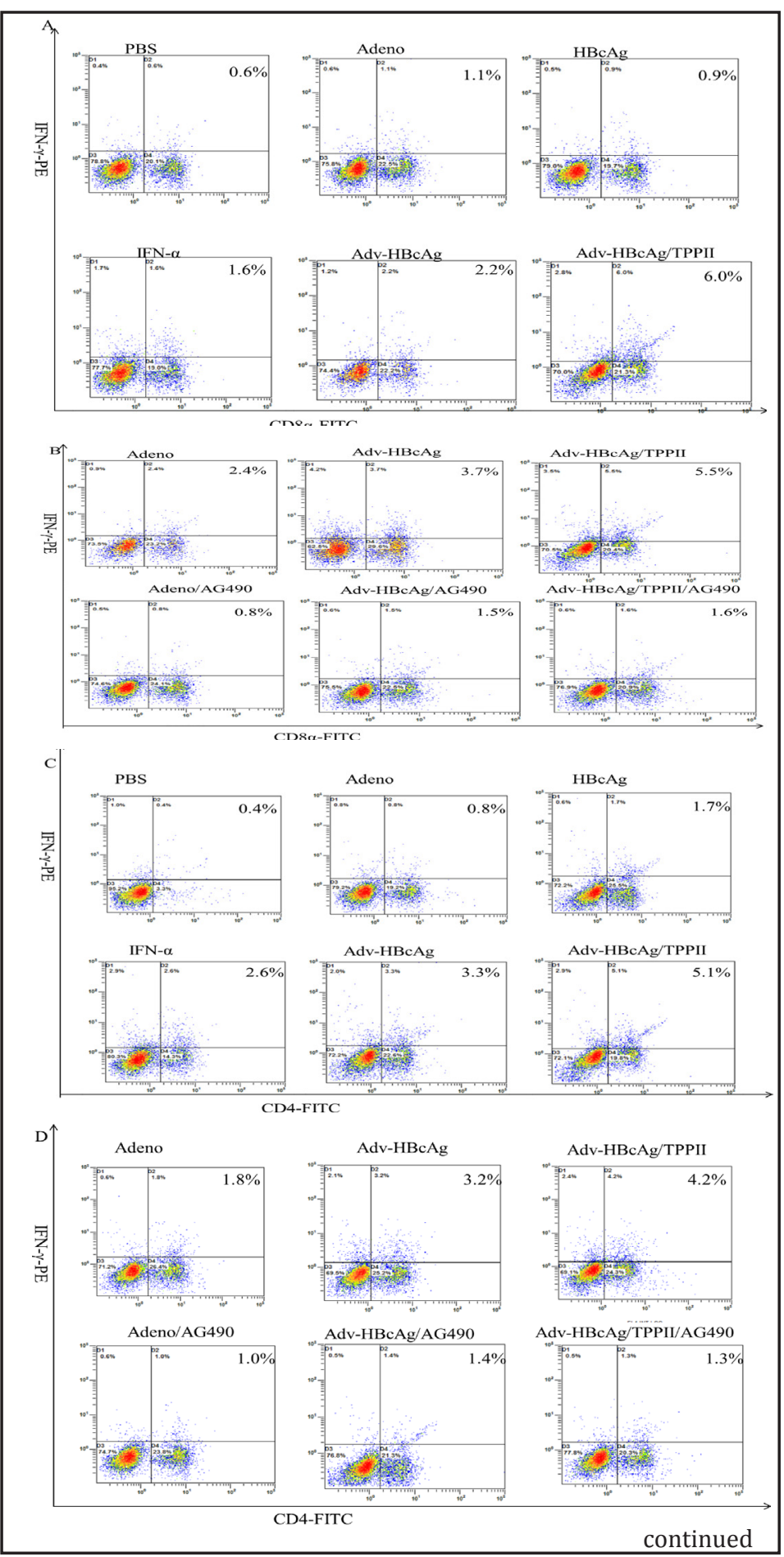

the Adv-HBcAg-TPPII group displayed higher IFN $\gamma^{+} \mathrm{CD}^{+}$and IFN $\gamma^{+} \mathrm{CD} 4^{+} \mathrm{T}$ lymphocytes in immunized HLA-A2 C57BL/ 6 mice compared with the other groups. However, the percentage of IFN $\gamma^{+} \mathrm{CD}^{+} \mathrm{T}$ lymphocytes in the Adv-HBcAg-TPPII/AG490 group was lower than that observed for the Adv-HBcAg-TPPII group.

Adv-HBcAg-TPPII improved the specific CTL response

Next, the CTL response was assessed by the LDH release assay. As shown in Fig. 3A, the Adv-HBcAg-TPPII group displayed higher percentages of specific cytolysis than did the other 


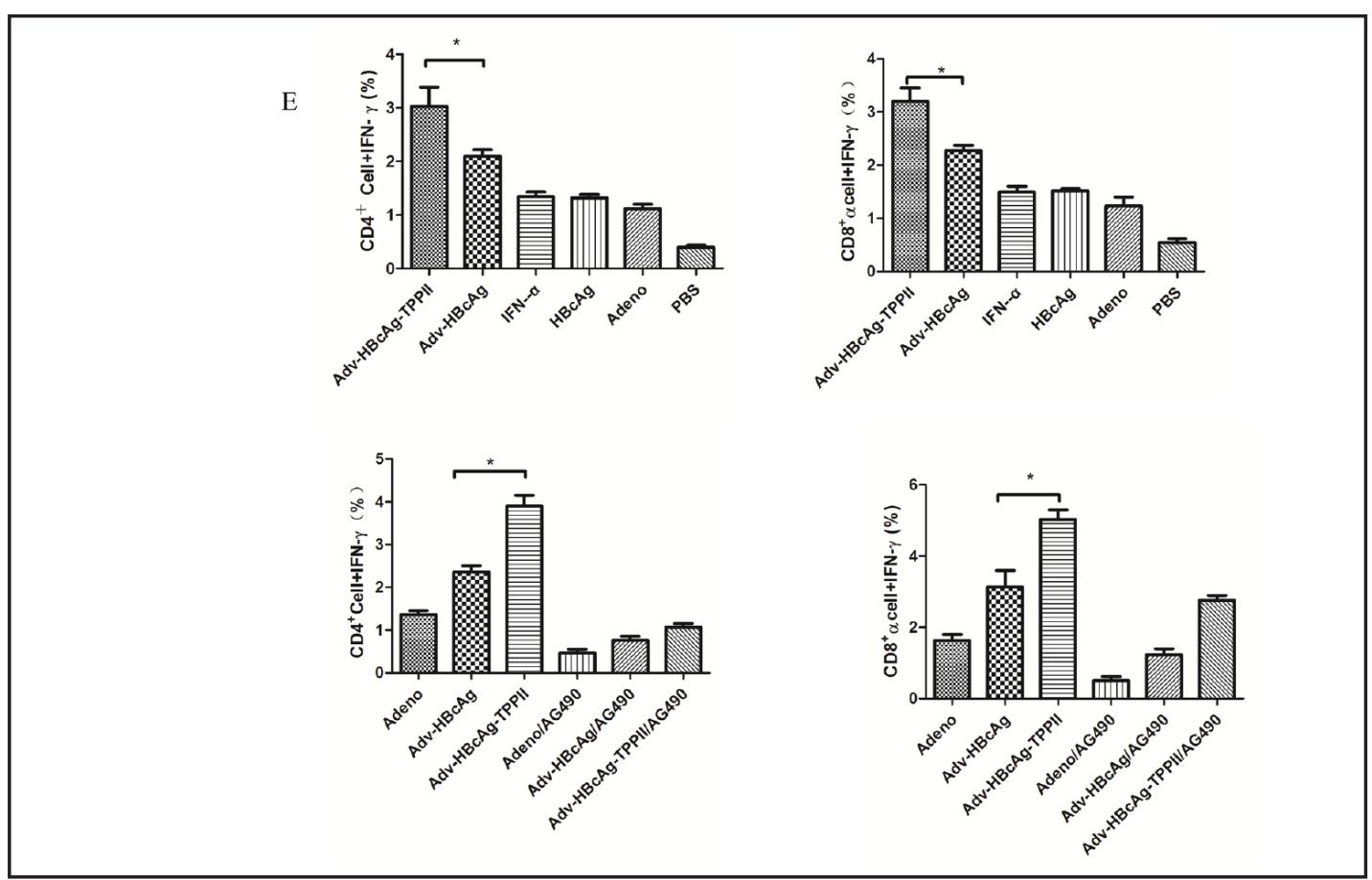

groups $(\mathrm{P}<0.01)$. Furthermore, the IFN- $\gamma-$ ELISPOT was used to evaluate the specific $\mathrm{T}$ cell responses to HBcAg. T cells were obtained from immunized mice, seeded in 96-well plates, and stimulated with the 87-95 amino acid peptide of HBcAg. As shown in Fig. 3B, the AdvHBcAg-TPPII group displayed higher HBcAg-specific T cell response levels compared with the other groups.

Serum HBsAg, HBV DNA, ALT, and AST levels

Serum was collected from $H-2 K^{d} \mathrm{HBV}$-transgenic BALB/c mice immunized with a recombinant adenovirus two weeks after the first and the last immunizations. The main purpose of this test was to assess whether transduction with Adv-HBcAg-TPPII could achieve virus clearance in HBV transgenic mice. Interestingly, the Adv-HBcAg/TPPII groups showed reduced HBsAg and HBV DNA levels (Fig. 4C and D) compared with the other groups. Furthermore, the serum AST and ALT levels were detected to evaluate whether AdvHBcAg-TPPII achieved virus clearance in HBV transgenic mice. Interestingly, the AST and ALT amounts were lower in this group compared with the other groups (Fig. 4A and B).

\section{Changes in gross liver morphology}

To further assess whether Adv-HBcAg-TPPII promoted virus clearance in HBV transgenic mice, its effect on liver tissue was evaluated by H\&E staining and immunohistochemistry. Liver tissues were obtained from recombinant adenovirus-immunized HBV mice two weeks after the last immunization. As shown in Fig. 5A, more inflammatory cell infiltration was observed in the Adv-HBcAg-TPPII group compared with the other groups. However, there was reduced inflammatory cell infiltration in the HBcAg, adenovirus, IFN- $\alpha$ and PBS groups. Moreover, as shown in Fig. 5B and C, immunohistological analysis suggested that the cytoplasmic HBsAg and nuclear HBcAg levels in hepatocytes of this group were lower compared with the other groups. However, increased cytoplasmic HBsAg and nuclear HBcAg amounts were found in PBS-treated mice.

Adv-HBcAg-TPPII enhanced the expression of JAK2, STAT1, STAT4 and Tyk2 at the mRNA and protein levels

To explore the underlying mechanisms, we assessed whether the JAK/STAT signaling pathway in the CTL response was stimulated by adenoviral vectors encoding HBcAg and 


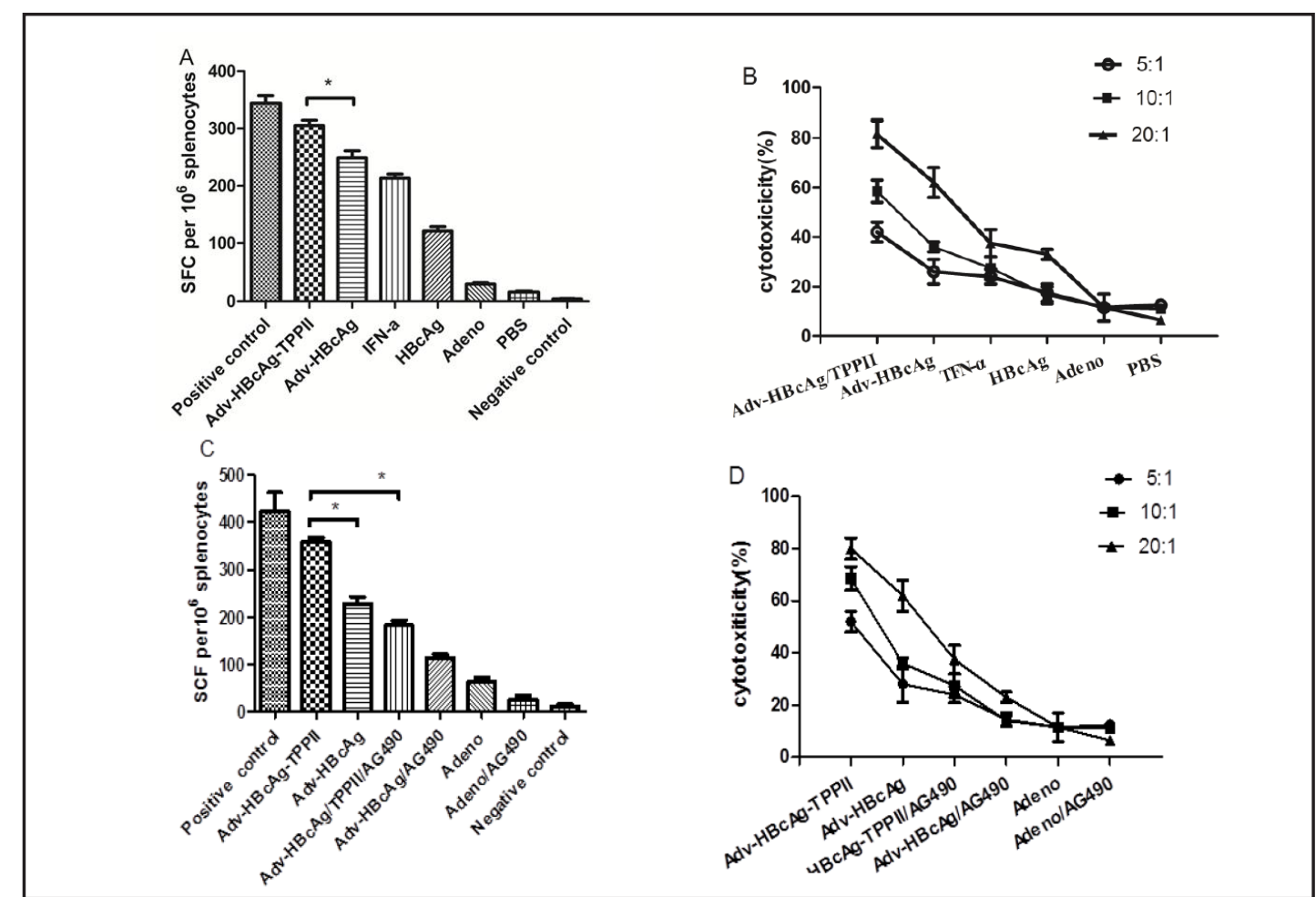

Fig. 3. CTL response assay and ELISPOT for IFN- $\gamma$ in HBV transgenic mice and C57BL/ 6 animals. (A) The number of IFN- $\gamma$ SFCs per $10^{6}$ splenocytes from HBV transgenic mice. Adv-HBcAg-TPPII induced higher IFN- $\gamma$ in vivo compared with the other groups. (B) CTL activities as the mean percentage of specific lysis at different effector-to-target (E:T) ratios (20:1, 10:1, and 5:1), as assessed using the LDH release assay in HBV transgenic mice. (C) The numbers of IFN- $\gamma$ SFCs per $10^{6}$ splenocytes from immunized C57BL/6 mice. AdvHBcAg-TPPII induced higher IFN- $\gamma$ in vivo compared with the other groups; after treatment with AG490, the IFN- $\gamma$ levels were reduced. (D) Specific CTL activity was assessed by the LDH release assay. CTL activity was expressed as the mean percentage of specific lysis at different effector-to-target (E:T) ratios (20:1, 10:1, and $5: 1)$. Data are representative of at least three independent experiments and are presented as the mean \pm SD $(\mathrm{n}=6) ;{ }^{*} \mathrm{P}<0.05$.

TPPII in HLA-A2 C57BL/6 mice. The expression levels of JAK2, Tyk2, STAT1 and STAT4 were analyzed by RT-PCR. As shown in Fig. 6A, the mRNA levels of JAK2, STAT1, STAT4 and Tyk2 were significantly increased in the Adv-HBcAg-TPPII group compared with the Adv-HBcAg, Adeno and Negative control groups. In addition, the mRNA expression levels of JAK2, STAT1, STAT4 and Tyk2 were lower in the Adv-HBcAg-TPPII/AG490 group. However, no significant differences in the Adv-HBcAg, Adeno or Adeno/AG490 groups were found $(\mathrm{P}>0.05)$. To explore the underlying mechanisms, we assessed the effects of Adv-HBcAg-TPPII on the JAK/STAT signaling pathway. Interestingly, the JAK2, STAT1, STST4 and TyK2 levels were significantly enhanced in the Adv-HBcAg-TPPII group compared with the other groups. After treatment with the specific inhibitor AG490, the JAK2, STAT1, STAT4 and TyK2 levels were reduced compared with the Adv-HBcAg-TPPII group. However, there were no statistically significant differences in mice immunized with Adv-HBcAg, Adeno, Adeno/AG490 or AdvHBcAg/AG490 (p>0.05) (Fig. 6B).

\section{Adv-HBcAg-TPPII increases T-bet expression and the T-bet/GATA-3 ratio}

Next, the expression of T-bet and GATA-3 in T cells from immunized $H-2 K^{d} \mathrm{HBV}$ transgenic BALB/c mice was assessed by RT-PCR and western blot. As shown in Fig. 7A, the T-bet amounts were significantly higher in the Adv-HBcAg-TPPII group than in the PBS, $\mathrm{HBcAg}$ and Adv-HBcAg groups. However, the GATA-3 levels were lower in the Adv-HBcAg- 


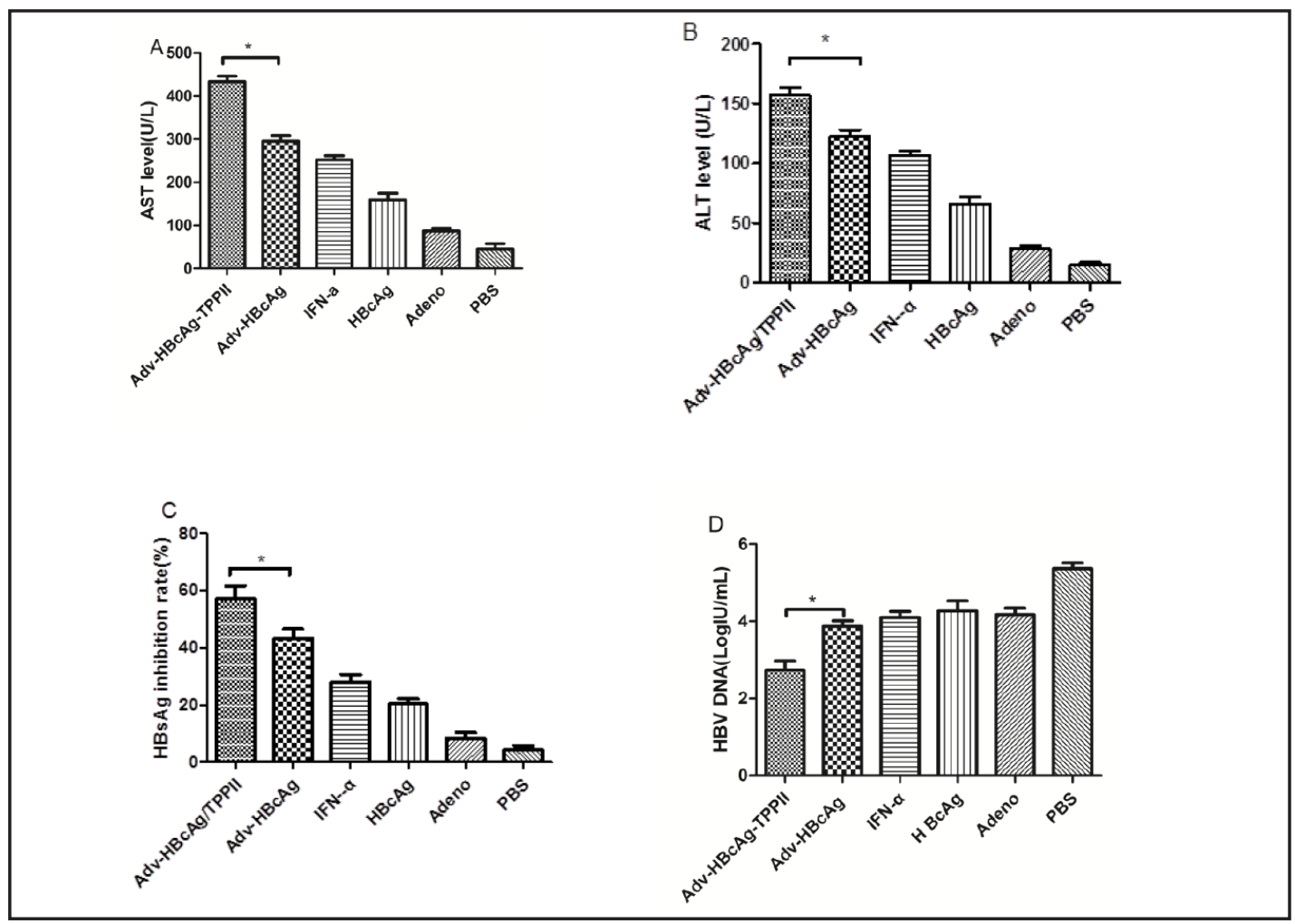

Fig. 4. Serum ALT and AST levels and HBsAg and HBV DNA amounts in HBV transgenic mice. AST (A) and ALT (B) levels in immunized HBV transgenic mice. HBsAg (C) and HBV (D) inhibition rates in immunized HBV transgenic mice. Data are the mean \pm SD from six mice per group; ${ }^{*} \mathrm{P}<0.05$.

TPPII group than in the PBS, HBcAg and Adv-HBcAg groups (Fig. 7B). The ratio of T-bet/ GATA-3 was increased in the Adv-HBcAg-TPPII group (Fig. 7C). These results indicated that Adv-HBcAg-TPPII may play an important role in the Th1/Th2 imbalance in $H-2 K^{d} \mathrm{HBV}$ transgenic BALB/c mice.

\section{Discussion}

Major histocompatibility complex (MHC) class I molecules provide a window for the immune system $[24,25]$. The proteolytic generation of peptides is the key point of the immune surveillance system, which considers proteins that are produced from longer gene products [26]. It is a fine and complicated process in cells because the system must be inclusive, rapid and reasonably precise [27]. Peptide production has been described clearly in recent years, and this process begins with the proteasome, which is good at generating peptides with a proper terminus for binding to class I molecules with high affinity $[28,29]$.

$\mathrm{CD}^{+} \mathrm{T}$ cells play a key role in immune surveillance for virally infected cells and tumors $[30,31]$ by participating in the clearance of persistent infection and mediating protective immunity [32]. In most cases, $C D 8^{+} \mathrm{T}$ cells could ignore the peptides presented on the surface of MHC class I molecules; however, abnormal peptides are surveyed by CD8+T cells. CTLs recognize and become activated to destroy the abnormal peptides.

Many studies have described a role for TPPII in MHC class I antigen presentation [3335]. Peptides that are bound to MHC class I molecules are byproducts of normal proteins in the cytoplasm [36, 37]. The proteasome is the main factor responsible for the initial cleavage of cellular proteins that are marked for degradation by the ubiquitination pathway [38]. The peptide fragments produced by the proteasome are rapidly degraded into amino acids by cytosolic aminopeptidases [39]. However, a small portion of peptides could escape this 
Fig. 5. Histological analysis and immunohistochemical staining for HBsAg and HBcAg in liver sections of HBV transgenic mice. (A) Liver sections were stained with hematoxylin and eosin. Inflammatory infiltrates were observed by light microscopy. Representative photographs are presented. Immunohistochemical staining for $\mathrm{HBsAg}(\mathrm{B})$ and $\mathrm{HBcAg}(\mathrm{C})$ was performed. Representative photographs are shown (original magnification: $\times 400$ ).

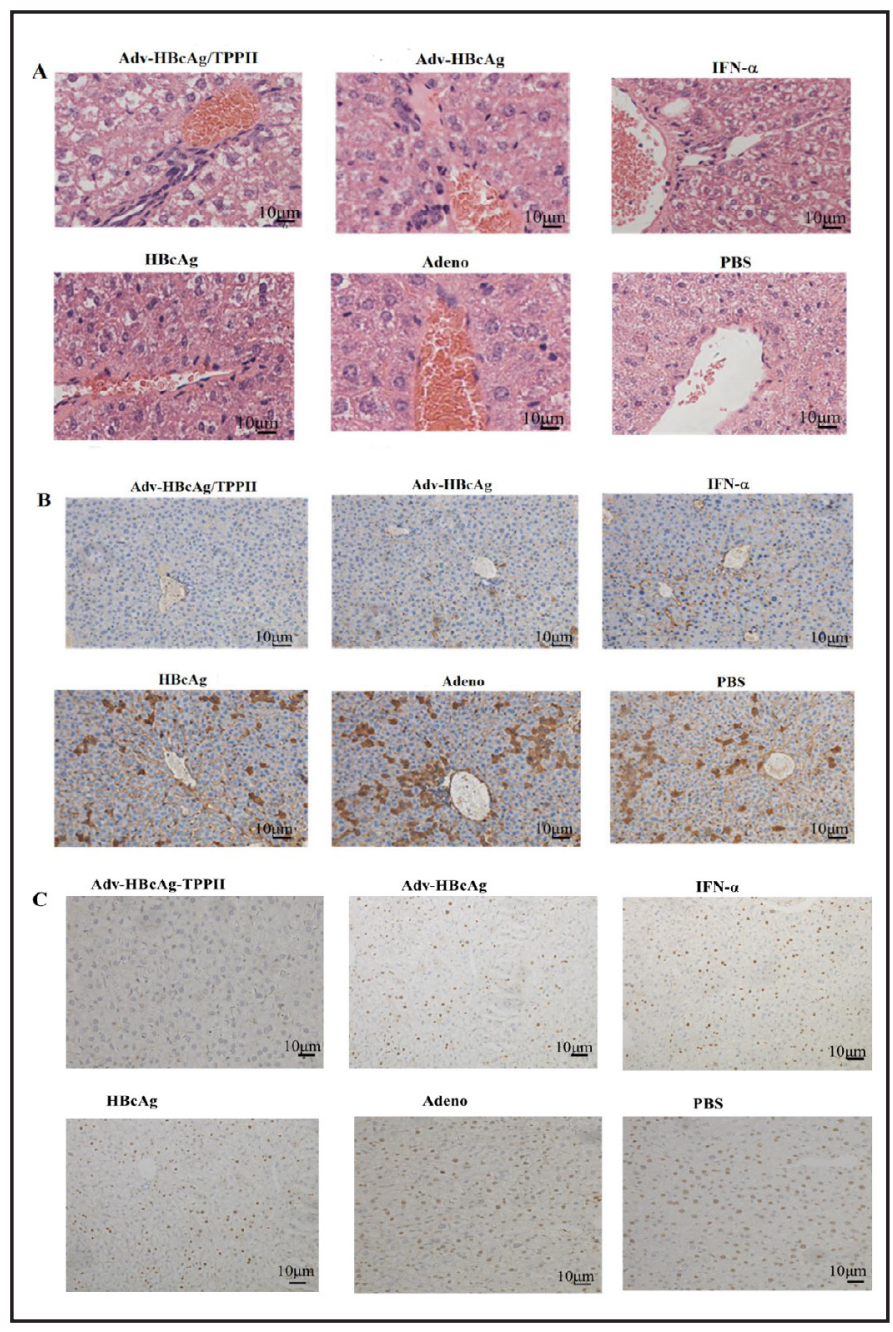

degradation and are transported to the endoplasmic reticulum (ER) (40) Further, MHC class I requires a proper size to form peptide-MHC-I complexes recognized by $\mathrm{CD}^{+} \mathrm{T}$ cells. TPPII is capable of degrading quite long peptides into shorter ones that have the size required for peptide-MHC-I complexes. TPPII may be essential for the proteasome in cellular protein degradation and generation. However, it was found that TPPII is not essential for MHC class I antigen presentation [16]. Therefore, the role of TPPII I in MHC class I antigen presentation remains controversial. To clarify this role we used an adenovirus vector containing HBcAg or TPPII genes to generate vaccines for mice. Then, we measured the CTL response and examined the underlying mechanisms.

Adenovirus vectors are widely used in the treatment of infectious diseases or cancers [3] because they are among the best carriers for delivering foreign genes into the host cells [40, 41]. Further, they can elicit antibody and $T$ cell responses. Adenoviruses have larger genomes compared with other vectors, which makes them more convenient for genetic manipulation. Indeed, adenoviruses constitute a better choice for carrying foreign genes [42]. Therefore, adenoviruses could be used as carriers to deliver the TPPII gene in vivo directly.

Our results indicated that Adv-TPPII could elicit a strong immune reaction in mice. The adenovirus vector encoding TPPII activated HBcAg-specific CD8 ${ }^{+} \mathrm{T}$ cells, and the Th1-like cytokines IL- 2 and IFN- $\gamma$ were markedly increased in $H-2 K^{d} \mathrm{HBV}$-transgenic BALB/c mice and HLA-A2 C57BL/mice. IL-2 and IFN- $\gamma$ are known to be associated with CD8 ${ }^{+} \mathrm{CTLs}$ in hepatitis $\mathrm{B}$ patient [43]. In addition, the direct injection of recombinant adenoviral vectors into $H-2 K^{d}$ HBV-transgenic BALB/c mice and HLA-A2 C57BL/ 6 mice altered the IL- 2 and IFN- $\gamma$ levels and the CTL response. However, no differences in the IL-4 and IL-10 levels were observe . 
Fig. 6. Expression levels of molecules related to the Janus kinase/ signal transducers and activators of transcription (JAK/STAT) pathway in C57BL/6 mice. Gene (A) and protein (B) expression levels of JAK2, Tyk2, STAT1, and STAT4. The JAK2, Tyk2, STAT1 and STAT4 amounts were significantly higher in C57BL/6 mice immunized with Adv-HBcAg-TPPII compared with the other groups at both the gene and protein levels. Data are the mean \pm SD $(n=6) ;{ }^{*} \mathrm{P}<0.05 .1$, Adv-HBcAg-TPPII; 2, Adv-HBcAg; 3, Adv-HBcAg-TPPII/AG490; 4, Adv-HBcAg/AG490; 5, Adeno; 6, Adeno/AG490.
A
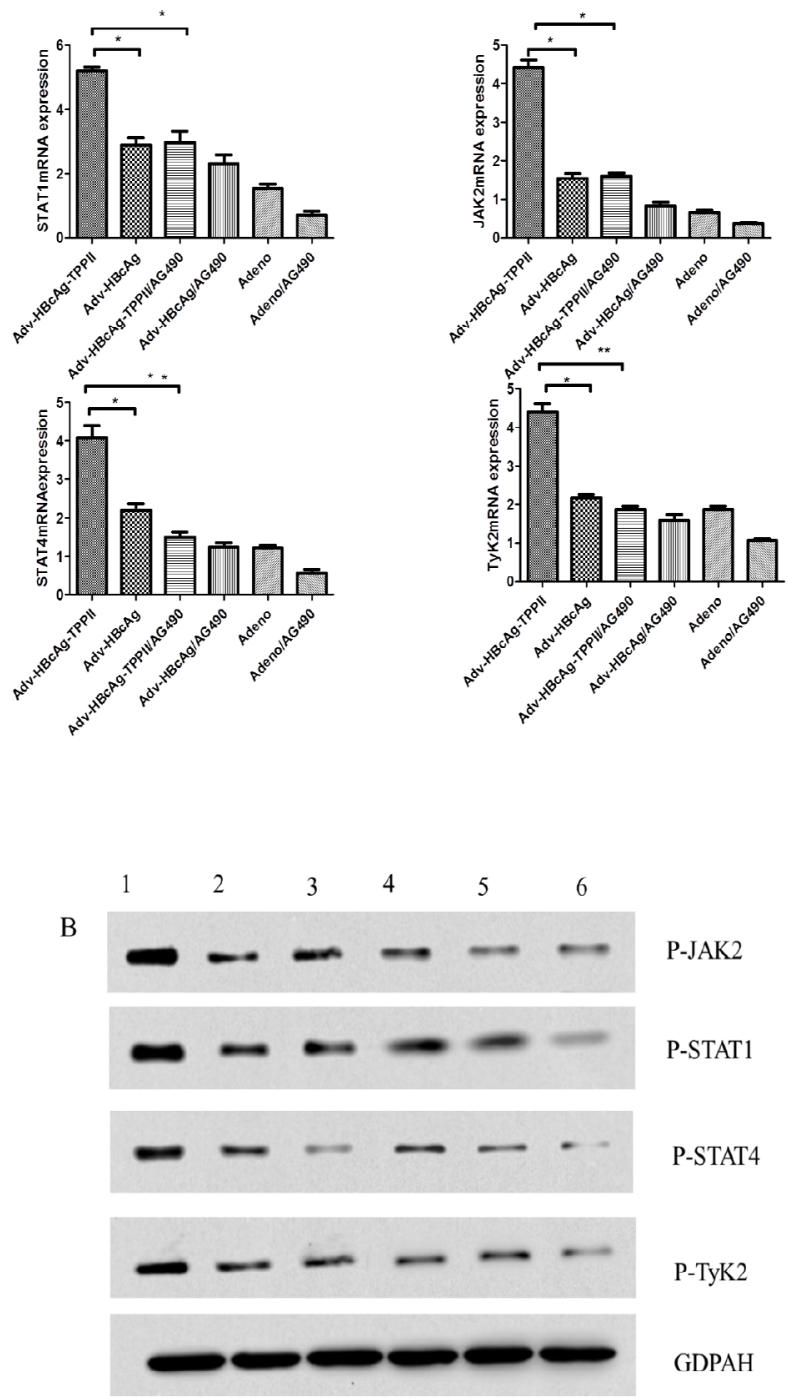

The main mechanism for virus clearance and replication control in acute HBV infection depends on HBV- CD8 ${ }^{+}$T cells [44]. Peptides that are bound to MHC class I molecules could be recognized as antigens and induce the release of $\mathrm{CD}^{+} \mathrm{T}$ cells. TPPII participates in the generation of MHC class I antigenic peptides [45, 46]. With the help of APCs, antigens are hydrolyzed into peptides by the proteasome [47]. Previous studies have indicated that HBcAg could activate the innate immunity [48]. Our previous study suggested that AdvHBcAg-TPPII could promote DC maturation and enhance HBcAg-specific CTLs in vitro.

In this study, CTLs were induced in vivo by vaccination with adenoviral vectors encoding HBcAg and TPPII. Flow cytometry and ELISPOT revealed increased T cell amounts in the Adv-HBcAg and Adv-HBcAg-TPPII mice groups, as detected by the expression of INF- $\gamma$, which is a marker of CTL activation [49]. These findings suggested a markedly increased number of IFN- $\gamma$-secreting CD8 ${ }^{+} \mathrm{T}$ cells, as well as CTL activity, in the Adv-HBcAg-TPPII group.

Reports have suggested that T helper-1 (Th-1)-type immune responses are associated with viral clearance during infection with hepatitis B virus (HBV) [50], which may be important for HBV treatment. As shown above, Adv-HBcAg and Adv-HBcAg-TPPII significantly induced IL-2 and IFN- $\gamma$ secretion, which indicated that Adv-HBcAg-TPPII triggers the Th1 immune response. 
Fig. 7. T-bet and GATA-3 levels in HBV transgenic mice. Gene expression levels of T-bet (A) and GATA-3 (B). (C) Ratio of T-bet to GATA-3. (D) Protein expression levels of T-bet and GATA-3. T-bet levels were significantly increased in the Adv-HBcAg-TPPII group compared with the Adv-HBcAg, HBcAg, and PBS groups, whereas the GATA3 amount was reduced $(\mathrm{n}=6$, ${ }^{*} \mathrm{P}<0.05$ ).

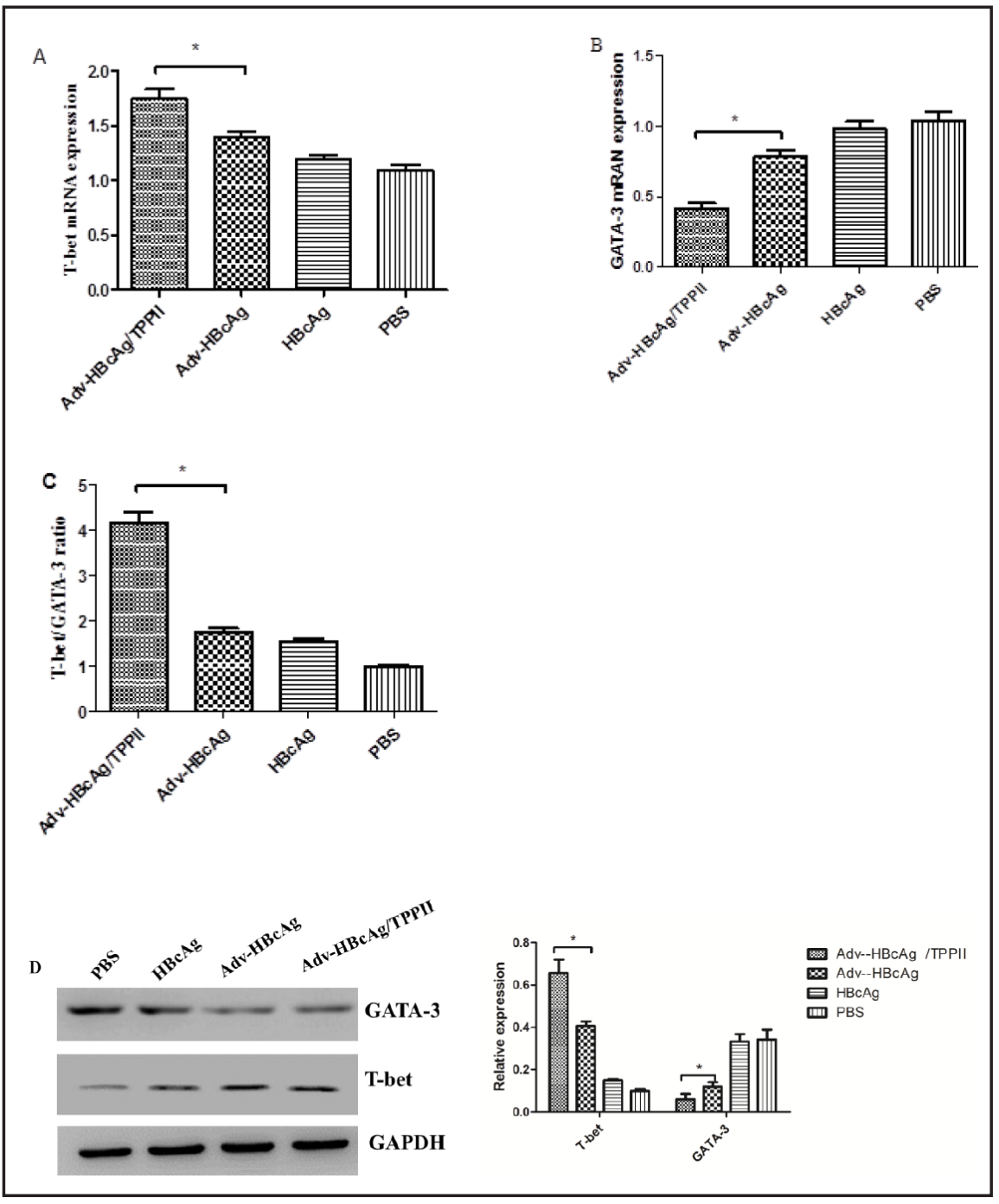

$H-2 K^{d} \mathrm{HBV}$-transgenic BALB/c mice have many features of the human disease, including T-cell unresponsiveness and the expression of HBV DNA and HBV-related antigens in the serum and liver; thus, they may constitute an appropriate animal model to explore treatment strategies [51]. In this study, spleen and liver tissues and blood samples were obtained from immunized $H-2 K^{d} \mathrm{HBV}$-transgenic BALB/c mice. Flow cytometry showed that Adv-HBcAgTPPII increased the amounts of IFN- $\gamma$ secreting $\mathrm{CD}^{+} \mathrm{T}$ cells in the spleen. In addition, AdvHBcAg-TPPII enhanced the CTL response in both $H-2 K^{d} \mathrm{HBV}$-transgenic BALB/c mice and HLA-A2 C57BL/6 $\left(H-2 K^{d}\right)$ mice. Furthermore, the HBsAg and HBV DNA levels were decreased in the Adv-HBcAg-TPPII group compared with other groups. However, the amounts of AST and ALT were higher than those found in other groups. This is consistent with specific CTL activity induced by Adv-HBcAg-TPPII.

Multiple studies have indicated that CTL activation of the second signal is induced by activated $\mathrm{CD}^{+} \mathrm{T}$ cells, with the initial $\mathrm{T}$ cell-mediated Th1 cell differentiation occurring via JAK/STAT signaling [52]. JAK2 and Tyk2 participate in the differentiation of Th1 cells, which activate the transcription factor STAT4. In addition, T-bet is associated with Th1 cell differentiation [53]. The JAK1/JAK3-STAT6 pathway participates in Th2 differentiation; GATA-3 is the specific factor in Th2 cells and can induce their differentiation [54]. The T-bet/ GATA-3 ratio provides a measure of the Th1/Th2 cytokine profile and reflects the condition of Th1/Th2 differentiation. As shown in Fig. 7A, the T-bet levels were markedly higher in the Adv-HBcAg-TPPII group than they were in the other groups. The expression of JAK/STAT 
signaling effectors was assessed by RT-PCR and western blot, as was that of T-bet and GATA3. As shown above, the JAK2, STAT1, STAT4 and Tyk2 levels were starkly increased in the Adv-HBcAg-TPPII group compared with the other groups in HLA-A2 C57BL/6 $\left(H-2 K^{d}\right)$ mice. However, after the injection of AG490, the amounts of JAK2, STAT1, STAT4 and Tyk2 were significantly reduced. In addition, the expression levels of T-bet and GATA-3 in $H-2 K^{d} \mathrm{HBV}$ transgenic BALB/c mice showed the opposite trends. Whereas T-bet was higher in the AdvHBcAg-TPPII group, the GATA-3 protein levels were reduced compared to the Adv-HBcAg, HBcAg and PBS groups.

These findings suggested that the JAK/STAT signal pathway participates in the CTL response, which is mediated by the adenoviral vector encoding TPPII and that Adv-HBcAgTPPII can induce Th1 differentiation by enhancing the T-bet levels and reducing the GATA-3 amounts and by causing Th1 and Th2 imbalance.

In conclusion, our findings indicated that adenoviral vector based vaccination with Adv-HBcAg-TPPII could trigger Th1 immune responses, CTL activity, and therapeutic effects in $H-2 K^{d} \mathrm{HBV}$-transgenic BALB/c mice and HLA-A2 C57BL/6 $\left(H-2 K^{d}\right)$ mice, with the participation of the JAK/STAT signaling pathway. Furthermore, T-bet upregulation and GATA-3 downregulation may participate in the induction of Th1 differentiation in this model. Consequently, vaccination with $\mathrm{Adv}-\mathrm{HBcAg} / \mathrm{TPPII}$ may be a potential therapeutic strategy to eradicate HBV.

\section{Acknowledgments}

This study was funded by the National Natural Science Foundation of China (grants No.81270502 and No.81470853).

\section{Disclosure Statement}

There are no conflicts of interests regarding the publication of this article.

\section{References}

1 Kao JH, Asselah T, Dou XG, Hamed K: Telbivudine therapy for chronic hepatitis B: a journey to identify super-responders and to optimize treatment using the roadmap model. J Gastroenterol Hepatol DOI:10.1111/jgh.13512.

2 Tian T, Sun D, Wang P, Wang H, Bai X, Yang X, Wang Z, Dong M: Roles of toll-like receptor 7 and 8 in prevention of intrauterine transmission of hepatitis B virus. Cell Physiol Biochem 2015;37:445-453.

-3 Zhang C, Zhou D: Adenoviral vector-based strategies against infectious disease and cancer. Hum Vaccin Immunother 2016;12:2064-2074.

4 McMahon BJ: Chronic hepatitis B virus infection. Med Clin North Am 2014;98:39-54.

5 He P, Zhang B, Liu D, Bian X, Li D, Wang Y, Sun G, Zhou G: Hepatitis B virus x protein modulates apoptosis in nrk-52e cells and activates fas/fasl through the MLK3-MKK7-JNK3 signaling pathway. Cell Physiol Biochem 2016;39:1433-1443.

6 Zhou C, Jin X, Tang J, Fei J, Gu C, Chen X: Association of CD40 -1C/T polymorphism in the 5'-untranslated region with chronic HBV infection. Cell Physiol Biochem 2015;35:83-91.

-7 Zhu D, Liu L, Yang D, Fu S, Bian Y, Sun Z, He J, Su L, Zhang L, Peng H, Fu Y: Clearing persistent extracellular antigen of hepatitis B virus: An immunomodulatory strategy to reverse tolerance for an effective therapeutic vaccination. J Immunol 2016;196:3079-3087.

8 Chisari FV, Isogawa M, Wieland SF: Pathogenesis of hepatitis B virus infection. Pathol Biol (Paris) 2010;58:258-266.

9 Sijts EJ, Kloetzel PM: The role of the proteasome in the generation of MHC class I ligands and immune responses. Cell Mol Life Sci 2011;68:1491-1502. 


\section{Cellular Physiology Cell Physiol Biochem 2017;41:423-438 \begin{tabular}{ll|l} 
and Biochemistry Published onlIne: January 27, 2017 & $\begin{array}{l}\text { (c) } 2017 \text { The Author(s). Published by S. Karger AG, Basel } \\
\text { www.karger.com/cpb }\end{array}$
\end{tabular}}

10 Usukura K, Kasamatsu A, Okamoto A, Kouzu Y, Higo M, Koike H, Sakamoto Y, Ogawara K, Shiiba M, Tanzawa H, Uzawa K: Tripeptidyl peptidase II in human oral squamous cell carcinoma. J Cancer Res Clin Oncol 2013;139:123-130.

11 Urban S, Textoris-Taube K, Reimann B, Janek K, Dannenberg T, Ebstein F, Seifert C, Zhao F, Kessler JH, Halenius A, Henklein P, Paschke J, Cadel S, Bernhard H, Ossendorp F, Foulon T, Schadendorf D, Paschen A, Seifert U: The efficiency of human cytomegalovirus pp65 (495-503) CD8+ T cell epitope generation is determined by the balanced activities of cytosolic and endoplasmic reticulum-resident peptidases. J Immunol 2012;189:529-538.

-12 Zhang J, Wong J, Gao G, Luo H: Tripeptidyl peptidase II serves as an alternative to impaired proteasome to maintain viral growth in the host cells. FEBS Lett 2011;585:261-265.

13 Rockel B, Kopec KO, Lupas AN, Baumeister W: Structure and function of tripeptidyl peptidase II, a giant cytosolic protease. Biochim Biophys Acta 2012;1824:237-245.

14 Chuang CK, Rockel B, Seyit G, Walian PJ, Schonegge AM, Peters J, Zwart PH, Baumeister W, Jap BK: Hybrid molecular structure of the giant protease tripeptidyl peptidase II. Nat Struct Mol Biol 2010;17:990-996.

15 Schlaak JF, Tully G, Lohr HF, Gerken G, Meyer zum Buschenfelde KH: HBV-specific immune defect in chronic hepatitis $\mathrm{B}(\mathrm{CHB})$ is correlated with a dysregulation of pro- and anti-inflammatory cytokines. Clin Exp Immunol 1999;115:508-514.

16 Kawahara M, York IA, Hearn A, Farfan D, Rock KL: Analysis of the role of tripeptidyl peptidase II in MHC class I antigen presentation in vivo. J Immunol 2009;183:6069-6077.

17 Tang TJ, de Man RA, Kusters JG, Kwekkeboom J, Hop WC, van der Molen RG, Schalm SW, Janssen HL: Intrahepatic CD8T-lymphocytes and HBV core expression in relation to response to antiviral therapy for chronic hepatitis B patients. J Med Virol 2004;72:215-222.

18 Kiessling R, Petranyi G, Karre K, Jondal M, Tracey D, Wigzell H: Killer cells: a functional comparison between natural, immune T-cell and antibody-dependent in vitro systems. J Exp Med 1976;143:772-780.

19 Crawford TQ, Ndhlovu LC, Tan A, Carvidi A, Hecht FM, Sinclair E, Barbour JD: HIV-1 infection abrogates CD8+T cell mitogen-activated protein kinase signaling responses. J Virol 2011;85:12343-12350.

20 Julius MH, Simpson E, Herzenberg LA: A rapid method for the isolation of functional thymus-derived murine lymphocytes. Eur J Immunol 1973;3:645-649.

21 Chen JH, Yu YS, Chen XH, Liu HH, Zang GQ, Tang ZH: Enhancement of CTLs induced by DCs loaded with ubiquitinated hepatitis B virus core antigen. World J Gastroenterol 2012;18:1319-1327.

22 Wang J, Dong S, Liu C, Wang W, Sun S, Gu J, Wang Y, Boraschi D, Qu D: Beta-glucan oligosaccharide enhances CD8(+) T cells immune response induced by a DNA vaccine encoding hepatitis B virus core antigen. J Biomed Biotechnol 2010;2010:645213.

23 Xia C, Liu Y, Chen Z, Zheng M: Involvement of interleukin 6 in hepatitis B viral infection. Cell Physiol Biochem 2015;37:677-686.

-24 Downs I, Vijayan S, Sidiq T, Kobayashi KS: CITA/NLRC5: A critical transcriptional regulator of MHC class I gene expression. Biofactors 2016;42:349-357.

25 Aptsiauri N, Cabrera T, Garcia-Lora A, Lopez-Nevot MA, Ruiz-Cabello F, Garrido F: MHC class I antigens and immune surveillance in transformed cells. Int Rev Cytol 2007;256:139-189.

-26 Dudek NL, Croft NP, Schittenhelm RB, Ramarathinam SH, Purcell AW: A systems approach to understand antigen presentation and the immune response. Methods Mol Biol 2016;1394:189-209.

27 Blander JM: The comings and goings of MHC class I molecules herald a new dawn in cross-presentation. Immunol Rev 2016;272:65-79.

28 Comber JD, Philip R: MHC class I antigen presentation and implications for developing a new generation of therapeutic vaccines. Ther Adv Vaccines 2014;2:77-89.

29 van Endert P: Intracellular recycling and cross-presentation by MHC class I molecules. Immunol Rev 2016;272:80-96.

-30 Gellin BG, Broome CV: Listeriosis. JAMA1989;261:1313-1320.

-31 Kaufmann SH, Rodewald HR, Hug E, De Libero G: Cloned listeria monocytogenes specific non-MHCrestricted Lyt-2+ T cells with cytolytic and protective activity. J Immunol 1988;140:3173-3179.

-32 Torres D, Kohler A, Delbauve S, Caminschi I, Lahoud MH, Shortman K, Flamand V: IL-12p40/IL-10 producing preCD8 $\alpha / \mathrm{Clec} 9 \mathrm{~A}+$ dendritic cells are induced in neonates upon listeria monocytogenes infection. PLoS Pathog 2016;12:e1005561. 


\section{Cellular Physiology Cell Physiol Biochem 2017;41:423-438 \begin{tabular}{ll|l} 
DOI: 10.1159/000456579 27,2017 & $\begin{array}{l}\text { O 2017 The Author(s). Published by S. Karger AG, Basel } \\
\text { www.karger.com/cpb }\end{array}$ \\
and Biochemistry Publisned online: January 27,
\end{tabular}}

33 Calis JJ, Reinink P, Keller C, Kloetzel PM, Kesmir C: Role of peptide processing predictions in T cell epitope identification: contribution of different prediction programs. Immunogenetics 2015;67:85-93.

34 York IA, Bhutani N, Zendzian S, Goldberg AL, Rock KL: Tripeptidyl peptidase II is the major peptidase needed to trim long antigenic precursors, but is not required for most MHC class I antigen presentation. J Immunol 2006;177:1434-1443.

-35 Firat E, Huai J, Saveanu L, Gaedicke S, Aichele P, Eichmann K, van Endert P, Niedermann G: Analysis of direct and cross-presentation of antigens in TPPII knockout mice. J Immunol 2007;179:8137-8145.

-36 Shastri N, Schwab S, Serwold T: Producing nature's gene-chips: the generation of peptides for display by MHC class I molecules. Annu Rev Immunol 2002;20:463-493.

- 37 Trombetta ES, Mellman I: Cell biology of antigen processing in vitro and in vivo. Annu Rev Immunol 2005;23:975-1028.

-38 Hochstrasser M: Ubiquitin and intracellular protein degradation. Curr Opin Cell Biol 1992;4:1024-1031.

-39 Reits E, Griekspoor A, Neijssen J, Groothuis T, Jalink K, van Veelen P, Janssen H, Calafat J, Drijfhout JW, Neefjes J: Peptide diffusion, protection, and degradation in nuclear and cytoplasmic compartments before antigen presentation by MHC class I. Immunity 2003;18:97-108.

-40 Schwenk R, Banania G, Epstein J, Kim Y, Peters B, Belmonte M, Ganeshan H, Huang J, Reyes S, Stryhn A, Ockenhouse CF, Buus S, Richie TL, Sedegah M: Ex vivo tetramer staining and cell surface phenotyping for early activation markers CD38 and HLA-DR to enumerate and characterize malaria antigen-specific CD8+ T-cells induced in human volunteers immunized with a plasmodium falciparum adenovirus-vectored malaria vaccine expressing AMA1. Malar J 2013;12:376.

41 Herath S, Le Heron A, Colloca S, Patterson S, Tatoud R, Weber J, Dickson G: Strain-dependent and distinctive T-cell responses to HIV antigens following immunisation of mice with differing chimpanzee adenovirus vaccine vectors. Vaccine 2016;34:4378-4385.

-42 Wu S, Kroeker A, Wong G, He S, Hou L, Audet J, Wei H, Zhang Z, Fernando L, Soule G, Tran K, Bi S, Zhu T, Yu X, Chen W, Qiu X: An adenovirus vaccine expressing Ebola virus variant makona glycoprotein is efficacious in Guinea pigs and nonhuman primates. J Infect Dis 2016,15;214:S326-S332.

43 Akbar SM, Horiike N, Onji M: Immune therapy including dendritic cell based therapy in chronic hepatitis B virus infection. World J Gastroenterol 2006;12:2876-2883.

44 Phillips S, Chokshi S, Riva A, Evans A, Williams R, Naoumov NV: CD8(+) T cell control of hepatitis B virus replication: direct comparison between cytolytic and noncytolytic functions. J Immunol 2010;184:287-295.

45 Meysman P, Ogunjimi B, Naulaerts S, Beutels P, Van Tendeloo V, Laukens K: Varicella-zoster virus-derived major histocompatibility complex class I-restricted peptide affinity is a determining factor in the HLA risk profile for the development of postherpetic neuralgia. J Virol 2015;89:962-969.

46 Loi M, Gannage M, Munz C: ATGs help MHC class II, but inhibit MHC class I antigen presentation. Autophagy 2016;12:1681-1682.

-47 Shen J, Hisaeda H, Chou B, Yu Q Tu L, Himeno K: Ubiquitin-fusion degradation pathway: a new strategy for inducing CD8 cells specific for mycobacterial HSP65. Biochem Biophys Res Commun 2008;365:621-627.

48 Balmasova IP, Yushchuk ND, Mynbaev OA, Alla NR, Malova ES, Shi Z, Gao CL: Immunopathogenesis of chronic hepatitis B. World J Gastroenterol 2014;20:14156-14171.

-49 Ranieri E, Popescu I, Gigante M: CTL ELISPOT assay. Methods Mol Biol 2014;1186:75-86.

-50 Chen Z, Cao J, Liao X, Ke J, Zhu S, Zhao P, Qi Z: Plasmids enriched with CpG motifs activate human peripheral blood mononuclear cells in vitro and enhance th-1 immune responses to hepatitis B surface antigen in mice. Viral Immunol 2011;24:199-209.

-51 Zhu J, Paul WE: Peripheral CD4+ T-cell differentiation regulated by networks of cytokines and transcription factors. Immunol Rev 2010;238:247-262.

-52 Guidotti LG, Chisari FV: Immunobiology and pathogenesis of viral hepatitis. Annu Rev Pathol 2006;1:23-61.

53 Chang X, Zhu A, Liu F, Zou L, Su L, Li S, Sun Y: Role of NF-KB activation and Th1/Th2 imbalance in pulmonary toxicity induced by nano NiO. Environ Toxicol DOI:10.1002/tox.22329.

-54 Lin Y, Zhou X, Guo W, Li Q, Pan X, Bao Y, He M, Zhu B, Lin X, Jin L, Yao R: Rhil-11 treatment normalized Th1/Th2 and T-bet/GATA-3 imbalance in human immune thrombocytopenic purpura (ITP). Int Immunopharmacol 2016;38:40-44. 